\title{
Women's Empowerment Through Small Farmers' Cooperatives: A Case Study from Eastern Nepal
}

\author{
Gehanath Poudel ${ }^{1}$ and Binod Pokharel ${ }^{2}$ \\ ${ }^{1} \mathrm{PhD}$ Scholar, Mewar University, NH - 79 Gangrar, Chittorgarh, Rajasthan-312 901, India \\ ${ }^{2}$ Research Supervisor, Professor of Anthropology, Central Department of Anthropology, \\ Tribhuvan University, Kathmandu, Nepal.

\section{Corresponding Author} \\ Gehanath Poudel \\ Email: poudelgehanath@gmail.com
}

\begin{abstract}
Small farmers cooperative limited (SFCL) is one of the very effective microcredit programs. It supports the rural farmer especially poor, marginalized, disadvantage and women of society by providing the saving and credit facilities. It has aimed to improve the socio-economic status of people and reduce the poverty level. The study aims to identify the contribution of SFCL on sociocultural and political empowerment of Nepalese women. The study was conducted in Ilam district among the 522 women beneficiaries of SFCL. The data were collected by applying the mixed method. Census method was used for this study. The analysis of data found that there was significant difference in socio-cultural and political empowerment of women after involving in SFCL program. Women have been empowered to maintain the social relationship, reduce the gender disparity, involve in social program, and participate in political program through SFCL activities. Women have expanded their network of relationship through saving and credit program. This study argues that women's access to economic resources changes their social status at household and community level. The study shows the need of expansion of SFCL program in hardto-reach areas also to empower the socially disadvantaged groups.
\end{abstract}

\section{KEYWORDS}

Cooperative, Empowerment, Small Farmer, Socio-Cultural, Women

\section{INTRODUCTION}

Small farmer cooperative limited (SFCL) supports the small farmers by providing the microcredit services; especially facility of saving and credit for poor, disadvantage and women. The Microcredit Summit (1997) has defined the term 'Microcredit' as "programs that provide credit for self-employment and other finance and business services (including savings and technical assistance) to very poor persons"(p. 2). Microfinance programs have the potential to transform 
power relations and empower the poor both men and women. In well-run microfinance programs, there is cordial and respectful relationship between the service providers and the clients that is inherently empowering (Cheston\& Kuhn, 2002, p. 4). Micro-finance services can contribute sustainable service to relieve from poverty, and consequently advance the human development indicators in considerable extent. It acts as a source for the supply of integrated services including savings, credit, training in different subjects, and other social and community programmes to the target rural poor population to lift them from below the poverty line (Mathema, 2008). Advocates of microcredit programs argue that empowerment of women in economic sectors becomes stepping stone to advance them in better social, cultural, and political dimensions of their social life. By means of this, the society becomes more equitable politically and economically (Christine Keating, 2010), p. 153). In developing countries, women empowerment is one of the important issues, because they are symmetrically integral part of society. Without involving more than half of society in production activities the prosperity of nation is almost impossible. Microfinance institutions are playing very important role in providing integrated microcredit services to the women, and involving them in production sector so as to empower their socio-economic capability (ibid).

More than half of the total population of Nepal is women. Women living in rural area of Nepal suffer from deplorable socio-economic conditions and this situation triggers to prevent them from the access of proper education. Since, the lack of education of rural people especially women obviously become less receptive of knowledge and skills and subsequently that makes them backward in socio-cultural life, resulting compelled to live in unworthy rural condition. Women work harder than men, though they are not in front line of socio-cultural and political activities. So, different types of programs have launched by SFCL to promote the social and economic condition of them. Some studies in the recent past have attempted to establish the relationship between credit program participation and some notion of women's empowerment. There are different elements used to measure the women's empowerment namely: power, autonomy and self-reliance, entitlement, participation and awareness and capability building etc. Most of the people generally think that empowerment is only the financial empowerment. Financial empowerment is only a single dimension of multiple facets. The person with sound financial position may not be empowered. Therefore, in this study the scholar has used women empowerment in socio-cultural and political sense. The social empowerment often addresses to those members of society who are excluded from participation in decision-making process of family and social activities. Most of the planners, intellectuals and bureaucrats and even general people talk about women empowerment make sense only on financial empowerment. Merely financial empowerment does not cover social empowerment, though there is strong association of financial empowerment and social empowerment. Social empowerment is a broader term. The elements comprising in social empowerment depends up on the nature of society. The aim of this study is to explore the women's empowerment, associated with microcredit based on Small Farmer Cooperative Limited (SFCL). 
The study has applied mixed methods: quantitative and qualitative design. Census approach was used to select the respondents. There were altogether 522 SFCL female members in the study area, all of them were enumerated for the study. Structured questionnaire was used to collect the data from 522 women of Ilam district who were directly connected with the microcredit activities of SFCL. Semi-structured checklist was used to collect the qualitative data through indepth interview and focus group discussion. The quantitative data are analyzed from the statistical software (SPSS) and qualitative data are retrospective narration presented under the related theme.

\section{RESULTS \& DISCUSSION}

Social dynamics are depending on the internal and external factors. Changes are the effect of certain causes so it has certain base of change. The study measured the change of women in relation to socio-cultural and political aspect through contribution of SFCL. SFCL has contributed to empower the women by providing the saving \& credit facilities; training orientation to gain different types of skills. It has also created the opportunities of networking with different organization when women have various options to gain the knowledge of their duties and rights. Women are socially and politically empowered along with economic empowerment, so economic empowerment is found the main base for other types of empowerment.

Ibarraran \& Shady (2009) defined women's empowerment as the expansion of the rights, resources and capacity of women to make decisions and act independently in social, economic, and political spheres. Esplen \& Brody (2007) identified that, in some areas of the world females are restricted for free mobility or travelling which in turn create hurdles and difficulties for participating in income generating or entrepreneurial activities, thus hindering the empowering process. Mariadoss (2012) noted that empowerment paves the way of higher level of mobility to women, and this mobility becomes impetus for involvement and participation in politics and decision making process.

This section of study defines the influence of SFCL in women's participation in sociocultural and political campaigns asking some relevant questions to the respondents.

\section{Socio-cultural empowerment of women through SFCL}

The data in Table1 contain the compared conditions of before and after involvement of women on socio-cultural empowerment through SFCL. The respondents were asked some relevant statements regarding socio-cultural and political participation of them in retrospective approach. The results showed that whether their participation in any social programs (marriage, worship) in community (before \& after respectively)option for 'yes' was $66.7 \%$ \& $99.0 \%$, and 'no' was by $33.3 \% \& 1.0 \%$ with 15.268 paired sample test and $\mathrm{p}=.000$ significance. Similarly, on involvement in any social groups (mother's group, user's groups), 'yes' was $43.5 \%$ \& $95.4 \%$ and 'no' was $56.5 \%$ \& $4.6 \%$ with 23.362 paired sample test and $\mathrm{p}=.000$ significance.

Table 1: Socio-cultural empowerment of women through SFCL

\begin{tabular}{|l|l|l|l|l|}
\hline Statements & Before & After & T & \\
\hline
\end{tabular}




\begin{tabular}{|c|c|c|c|c|c|c|c|}
\hline & & $\mathbf{N}$ & $\%$ & $\mathbf{N}$ & $\%$ & & $\begin{array}{l}\text { Sig. } \\
\text { tailed })\end{array}$ \\
\hline \multirow{2}{*}{$\begin{array}{l}\text { Female participation in any social programs } \\
\text { (marriage, worship) in community }\end{array}$} & Yes & 348 & 66.7 & 517 & 99.0 & \multirow{2}{*}{15.268} & \multirow{2}{*}{.000} \\
\hline & No & 174 & 33.3 & 5 & 1.0 & & \\
\hline \multirow{2}{*}{$\begin{array}{l}\text { Female's involvement in any social groups } \\
\text { (mothers' group, users groups) }\end{array}$} & Yes & 227 & 43.5 & 498 & 95.4 & \multirow{2}{*}{23.362} & \multirow{2}{*}{.000} \\
\hline & No & 295 & 56.5 & 24 & 4.6 & & \\
\hline \multirow{2}{*}{$\begin{array}{l}\text { Female's responsibility in solving the intellectual } \\
\text { and social problems of communities }\end{array}$} & Yes & 165 & 31.6 & 406 & 77.8 & \multirow{2}{*}{20.666} & \multirow{2}{*}{.000} \\
\hline & No & 357 & 68.4 & 116 & 22.2 & & \\
\hline \multirow{2}{*}{$\begin{array}{l}\text { Female's visit in health post/hospital for health } \\
\text { treatment }\end{array}$} & Yes & 390 & 74.7 & 458 & 87.7 & \multirow{2}{*}{5.385} & \multirow{2}{*}{.000} \\
\hline & No & 132 & 25.3 & 64 & 12.3 & & \\
\hline
\end{tabular}

Source: Field Survey, 2016

Results on bearing any responsibility in solving the intellectual and social problems of communities, 'yes' was $31.6 \%$ \& $77.8 \%$, and 'no' was $68.4 \% \& 22.2 \%$ with 20.666 paired sample test and $\mathrm{p}=.000$ significance. Finally, results showed on visiting health post/ hospital for own health treatment alone, 'yes' was $74.7 \%$ \& $87.7 \%$, and 'no' was $25.3 \%$ \& $12.3 \%$ with 5.385 paired sample test and $\mathrm{p}=.000$ significance.

This analysis data reflect the improved condition of women in socio-cultural empowerment through the help of SFCL due to increased rate of participation of women in socio-cultural activities more than before with paired sample test and $p=.000$ significance.

The study conducted by Sudipta De and Debnarayan Sarker showed that the level of women's empowerment under female borrower group is considerably higher (ranging between 2.50 and 2.84) than other control group. This study suggests that 'empowerment of women' participating in the microcredit programme has a positive and significant effect on their children's nutritional status and protein-intake of their households (De \& Sarker, 2011, pp. 61-64). Upadhyay said, restriction on freedom of travelling movement depends upon socio-cultural factors that how society and family think about the women rights (Upadhyay, 2009). Today, more than ever, women are becoming active participants and full protagonists of the development process. However, many obstacles and barriers continue to complicate women's participation. In many parts of the world, large numbers of women remain isolated, unorganized, and poor and constrained by socio-cultural and legal structures that restrict their access to, and involvement in, the development process (Mokate, 2004).

\section{Political empowerment of women through SFCL}

The data in this Table 2 show the situation/condition of political empowerment of women through SFCL. This comparative result shows before and after involvement on SFCL programs. The data were collected from 522 respondents. Respondents were asked some relevant statements about political activities which they experienced before and after involvement in SFCL giving choice of "yes" and "no" options of response.

In the case of whether they participate in casting vote in election, the comparative data (before \& after respectively) shows 'yes' option by $72.0 \% \& 93.1 \%$ and 'no' option by $28.0 \% \&$ 
$6.9 \%$ with 11.661 paired sample test and $p=.000$ significance. Similarly, in the case of whether they cast vote to the candidate of own choice, $65.7 \% \& 89.1 \%$ answered 'yes' and rest of them $34.3 \%$ \& $10.9 \%$ answered 'no' with 12.437 paired sample test and $\mathrm{p}=.000$ significance.

When asked whether they attend the speeches of election campaigns, the result found 'yes' by $34.3 \%$ \& $10.9 \%$ and 'no' by $68.0 \%$ \& $32.2 \%$ with 16.385 paired sample test and $\mathrm{p}=.000$ significance. Similarly, on the query of whether they involve oneself in election campaign of candidate of own choice, the result found $24.3 \%$ \& 53.6\% 'yes' and $75.7 \%$ \& $46.4 \%$ 'no' with 13.100 paired sample test and $\mathrm{p}=.000$ significance.

Results on whether they have updated knowledge of changing political situation, it is found $44.4 \% \& 73.0 \%$ 'yes' and 55.6\% \& 27.0\% 'no' with 12.385 paired sample test and $\mathrm{p}=.000$ significance.

Table 2: Political empowerment of women through SFCL

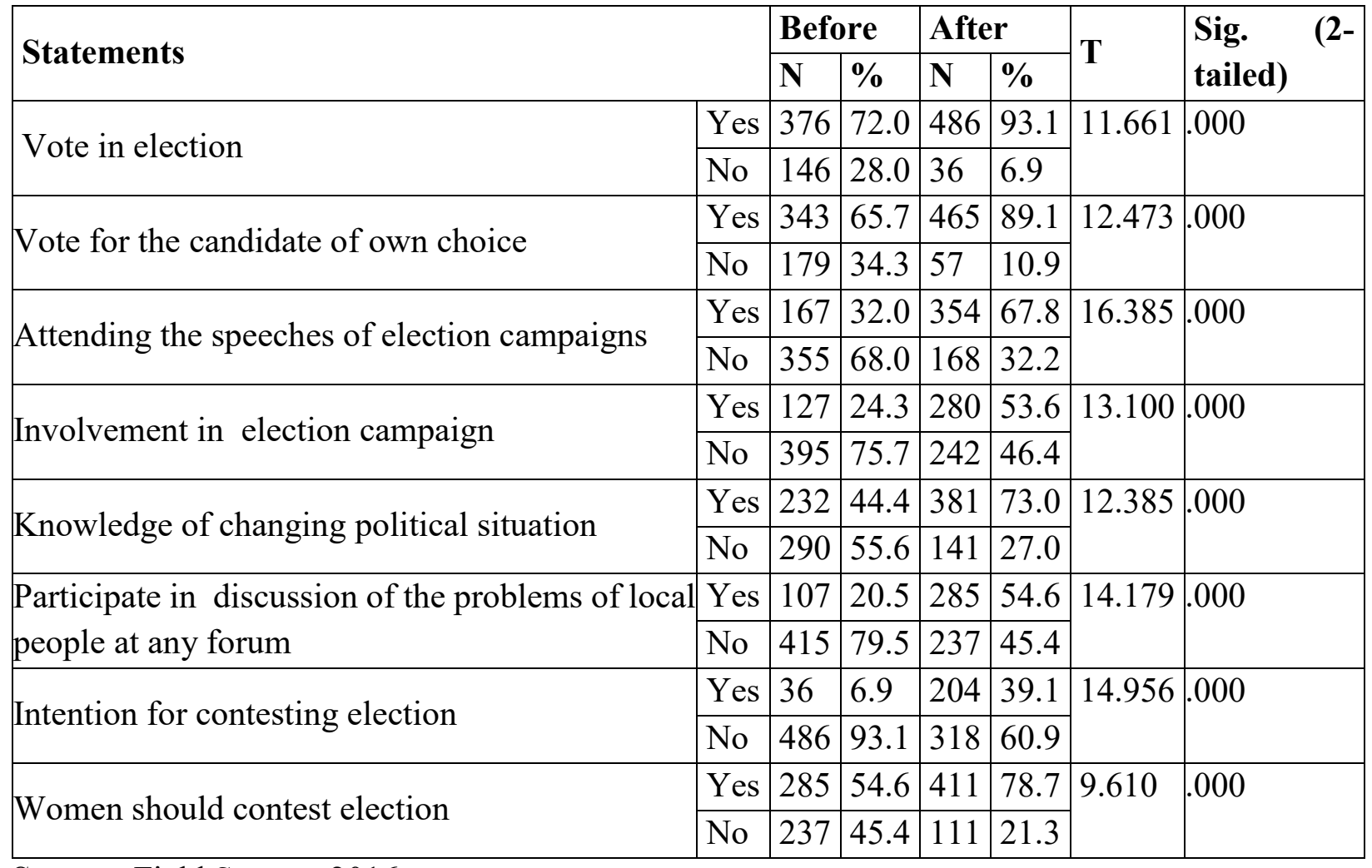

Source: Field Survey, 2016

Similarly, on the query of whether they participate in discussion in the problems of local people at any forum, the result found $20.5 \%$ \& 54.6\% 'yes' and 79.5\% \& 45.4\% 'no' with 14.179 paired sample test and $\mathrm{p}=.000$ significance. When they are asked about their intention of contesting election, the result found $6.9 \%$ \& 39.1\% 'yes' and $93.1 \%$ \& 60.9\% 'no' with 14.956 paired sample test and $\mathrm{p}=.000$ significance. Likewise, when asked about their thought whether women should contest election, the result found $54.6 \%$ \& $78.7 \%$ 'yes' and $45.4 \%$ \& $21.3 \%$ 'no' with 9.610 paired sample test and $\mathrm{p}=.000$ significance. In overall, the study found the significant contribution of SFCL to empower the women from the social and political perspective. The finding 
of previous study also corroborated to the finding of this study. A study done by Dr. Sabahat Akram, Imrab Shaheen \& Safina Mansha Kiyyani( 2015, p. 205) found that there was positive relationship between the freedom of mobility and economic freedom from Pearson correlation coefficient with $\mathrm{r}=.549, \mathrm{n}=114, \mathrm{p}=.0000$. That entailed that freedom of mobility and freedom of economic activities complement each other and have a positive impact on women empowerment.

Women's representation in elected office is slowly advancing in the Organization for Security and Co-operation in Europe (OSCE) region. Where, in 1996, women held only 13.8 percent (Women in National Parliaments, 1997) of seats in the single or lower chamber of national parliaments, and only 16.5 percent in 2000 ("Women in National Parliaments, 2000). OSCE is the world's largest security-oriented intergovernmental organization. Today, women constitute 24.8 percent of all members of the lower house in national parliaments in the OSCE region, or almost one in four (Women in National Parliament, 2014). The participation of women as protagonists in politics is still far from representing the composition of Brazilian society. The number of female candidates has grown in the last elections, from 935 in 2010 to 1755 in 2014 . Nevertheless, women are still underrepresented in the elected posts. The current Congress has only 51 women representatives, which mean $9.9 \%$ of the 513 congresspersons - just one percentage point above the previous period (Paula, 2015).

\section{Respondents' perception on role of SFCL to change the status of women in society.}

Table 3 shows the respondents' perception on role of SFCL to change the status of women in society. In this study respondents were provided five options viz. strongly agree, agree, neutral, disagree, and strongly disagree to express their range of perception in some relevant socio-cultural and political activities relating to women empowerment.

The respondents were asked whether SFCL has role to aware women about their rights of vote in election in their society, result found $14.2 \%$ of them strongly agree, $37.5 \%$ agree, $10.7 \%$ neutral, $27.8 \%$ disagree and $9.8 \%$ of them strongly disagree with 2.81 mean agreement. When they were asked whether SFCL empowers women to choose the appropriate candidate to vote in election, result found $10.3 \%$ of them strongly agree, $17.6 \%$ of them agree, $31.6 \%$ of them remain neutral, $28.2 \%$ of them disagree and rest $12.3 \%$ strongly disagree with 3.14 mean agreements. On question when asked whether SFCL empowers women to take membership of political parties, result showed that $7.1 \%$ 'strongly agree', $12.5 \%$ 'agree', 35.2\% 'neutral', 29.9\% 'disagree' and 15.3\% 'strongly disagree' with 3.34 mean agreements.

Likewise, when asked whether SFCL empowers women to take leadership in political parties, result found $6.7 \%$ respondents strongly agree, $11.9 \%$ agree, $34.7 \%$ remain neutral, $30.8 \%$ disagree and $15.9 \%$ of them strongly disagree with 3.37 mean agreements. In the same way, when asked whether SFCL empowers women to be elected as candidate in election, result found $6.5 \%$ respondents strongly agree, $15.1 \%$ just agree, $33.7 \%$ remain neutral, $31.4 \%$ followed disagree and $13.2 \%$ of them stood for strongly disagree with 3.30 mean agreements. 
Results on when asked whether SFCL aware women about the women empowerment and social inclusion program of Nepal government, it is found $21.1 \%$ respondents strongly agree, $56.5 \%$ agree, $8.0 \%$ neutral, $12.5 \%$ disagree and rest of $1.9 \%$ are strongly disagree with 2.18 mean agreements. Likewise, in query of whether SFCL encourages women to form the women groups in communities, result found $43.5 \%$ respondents strongly agree, $52.7 \%$ agree, $2.5 \%$ neutral, $1.3 \%$ disagree and $0 \%$ none of them for strongly disagree with 1.62 mean agreements. Similarly, when asked whether SFCL supports to develop the social relationship of women in their neighbor, the result found $31.8 \%$ respondents strongly agree, $51.3 \%$ agree, $7.1 \%$ neutral, $9.6 \%$ disagree and $0.2 \%$ strongly disagrees with 1.95 mean agreements.

Table 3: People perception on role of SFCL to change the status of women in society

\begin{tabular}{|l|l|l|l|l|l|l|l|l|}
\hline Statements & & & & & & & \\
& & & & \\
\end{tabular}

Source: Field Survey, 2016 
Finally, when respondents were asked whether SFCL supports to reduce the gender disparity in family and society, result found $28.0 \%$ respondents strongly agree, $52.1 \%$ agree, $4.8 \%$ neutral, $14.4 \%$ disagree and .8\% strongly disagree with 2.08 mean agreements.

According to Khan \& Bibi (2011) male attitude towards female regarding income generating activities seems to have been improved which is a positive sign towards women's economic independence and decision making capability. Empowerment revolves around production activities, awareness, economic independence and participation in decision making process in domestic and social activities. Awareness comes through knowledge and different initiations regarding income generation (Ahmed, 1999). But, there are some obstacles and barriers that limit women's opportunity to participate in different aspects of domestic and social life. The initiatives taken by government and other public institutions to overcome barriers for equitable participation of women in economic, social and political activity vary greatly among countries (Mokate, 2004). Although women turn up in large numbers in every political election whereby they constitute more than half of the population in many countries, yet they are visibly absent in decision making positions in the Government, parasternal organizations and private companies. Women remain concentrated in the so-called "female professions" and at the very best in the middle management positions and hence miss the decision-making processes at higher levels (Losindilo, Mussa, \& Akarro, 2010).

\section{Overall role of SFCL to empower the women}

The respondent beneficiary women of SFCL have experienced the strength of empowerment individually. It may vary person to person, though its service delivery system is impartial. Given Table4 reveals the nature of role of SFCL to empower the women from the 522 respondents. Regarding this, different relevant statements to overall women empowerment were asked to all respondents. In the first statement, respondents were asked whether SFCL has role to increase the decision making power of women in household level discussion. The result found $47.3 \%$ for perfect role, $45.8 \%$ for slight role and $6.9 \%$ for no role with 1.60 mean roles. Similarly, in the second statement they were asked whether SFCL has role to empower women increasing their access on household level economy. The result showed that $51.0 \%$ preferred perfect role, $41.4 \%$ preferred slight role and $7.7 \%$ of them preferred no role with 1.57 mean roles.

Table 4: Overall role of SFCL to empower the women

\begin{tabular}{|c|c|c|c|c|c|c|}
\hline Statements & 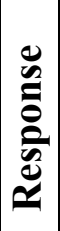 & 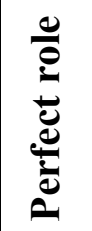 & 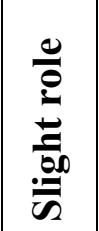 & $\begin{array}{l}\frac{0}{0} \\
\stackrel{0}{0} \\
\text { Z }\end{array}$ & 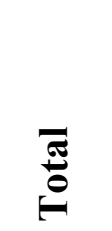 & 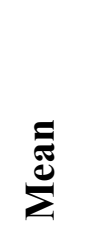 \\
\hline \multirow{2}{*}{$\begin{array}{l}\text { SFCL has role to increase the decision making power of } \\
\text { women in household level discussion }\end{array}$} & $\mathrm{N}$ & 247 & 239 & 36 & 522 & \multirow[t]{2}{*}{1.60} \\
\hline & $\%$ & 47.3 & 45.8 & 6.9 & 100.0 & \\
\hline \multirow{2}{*}{$\begin{array}{l}\text { SFCL has role to empower women increasing their access on } \\
\text { household level economy }\end{array}$} & $\mathrm{N}$ & 266 & 216 & 40 & 522 & \multirow[t]{2}{*}{1.57} \\
\hline & $\%$ & 51.0 & 41.4 & 7.7 & 100.0 & \\
\hline
\end{tabular}


ISSN: 2362-1303 (Paper) | eISSN: 2362-1311(Online)

\begin{tabular}{|c|c|c|c|c|c|c|}
\hline \multirow{2}{*}{$\begin{array}{l}\text { SFCL has role to establish the women's rights in household } \\
\text { level assets }\end{array}$} & $\mathrm{N}$ & 182 & 301 & 39 & 522 & \multirow[t]{2}{*}{1.73} \\
\hline & $\%$ & 34.9 & 57.7 & 7.5 & 100.0 & \\
\hline \multirow{2}{*}{$\begin{array}{l}\text { SFCL has role to establish the social identity of women in their } \\
\text { community }\end{array}$} & $\mathrm{N}$ & 224 & 275 & 23 & 522 & \multirow[t]{2}{*}{1.61} \\
\hline & $\%$ & 42.9 & 52.7 & 4.4 & 100.0 & \\
\hline \multirow{2}{*}{$\begin{array}{l}\text { SFCL has role to encourage the women in political } \\
\text { participation }\end{array}$} & $\mathrm{N}$ & 80 & 180 & 262 & 522 & \multirow[t]{2}{*}{2.35} \\
\hline & $\%$ & 15.3 & 34.5 & 50.2 & 100.0 & \\
\hline
\end{tabular}

Source: Field Survey, 2016

In the third statement, they were asked whether SFCL has role to establish the women rights in household level assets. The result found that 34.9\% respondents had perfect role, 57.7\% respondents had slight role and $7.5 \%$ respondents had no role with 1.73 mean roles. In the fourth statement, they were asked whether SFCL has role to establish the social identity of women in their community. The result found $42.9 \%, 52.7 \%$ and $4.4 \%$ respectively for perfect role, slight role and no role with 1.61 mean roles. Finally, they were asked whether SFCL has role to encourage the women in political participation. The result found that $15.3 \%$ preferred for perfect role, $34.5 \%$ preferred for slight role and 50.2\% preferred no role with 2.35 mean roles.

From the analysis of mean value of tabulated data showed that comparative role of SFCL found more significant to empower the economic status than the political empowerment, which is similar to the findings of Rathiranee Yogendrarajah. He has concluded that there is strong relationship between micro credit and economic empowerment than social empowerment (Rathiranee, 2012).

From the key informants interview and group discussion with beneficiaries of SFCL itis found that women were more empowered economically rather than socio-culturally and politically. It might be the reason that economic activity is the main objective of SFCL. It is focused to changes the society through the strong economic strength. However, SFCL launched social activities concurrently side by side. Among the key informants Tek Bahadur Aale - resident of Sriantuis running Home-stay business since 15 years has also encouraged his wife to be a member of SFCL. He said that SFCL has not only contributed in improving the economic status of women but it has also strengthened the knowledge of people through different type of training, even though the economic strength is the prime. He added that knowledge building is one important activity of SFCL, so that used to conduct different skills based training. In last consecutive three years, SFCL sent some youths to Israel for agriculture training. Several such types of training are being conducted since the genesis of SFCL to strengthen women in socio-cultural dimensions. In such training equitable participation of spouse is guaranteed to streamline the acceptance of new thoughts in family and in community.

Mrs. Dipa Thakuri reported that SFCL has worked in different social development activities. It has supported to build toilet in individual household. It has provided the training of health and sanitation and provided raw materials to build toilet and improved cooking stoves. It supported the health awareness programs. Mr. Dharani Ghimire said that SFCL has established coordination with some hospitals to provide the health service facilities to SFCL members. It made cards for individual members, so that they could get up to $30 \%$ discount in health checkups and 
treatments. Mrs. Santa Khadka of Samalbung shared that SFCL has distributed the strictures to sub-health posts and Community Health Volunteers to support the serious patients as a part of social services.

\section{Happiness from SFCL}

I have got knowledge of SFCL in 1989 from employees of Agriculture Development Bank, since then continuously I am participating in all activities of SFCL. I took loan from SFCL and started small-scale business: shop in own home. Now, I have no problems of money for running any business or social or cultural program. I take the decision of every activities of household. I am aware on the right and duties of women in family and society. I got the knowledge of health and sanitation through the activities of SFCL, then I build cemented toilet and set the improved cooking stove. I involve in social activities and could put my voice among the larger population. I am happy that all these changes become possible after involving in SFCL.

Amrita Giri-Samalbung - 3, Ilam

The findings of previous study are analogous to the findings of this study. The logic of microfinance potential for empowerment is similar to the economic model of empowerment: microfinance makes women economically independent by putting capital and financial resources in their hands. Economic independence results in higher bargaining power for women in their households and communities, and subsequently results in higher prestige and self-esteem (Kulkarni, 2011). Operating via a Social Finance Network across all sectors and regions, the SFP contributes to achieving gender equality and women's empowerment through the promotion of more inclusive financial systems. The SFP's Microfinance for Decent Work action research aims to reduce vulnerability, invest in job creation and strengthen social partners' capacity to improve access to financial services. Innovation Facility, an experimental programme designed to improve men and women's ability to cope and mitigate risk through micro-insurance (Microcredit Summit Campaign, 2007).

\section{CONCLUSIONS}

SFCL has positive impact on women empowerment; first in economic sense and consequently socio-cultural dimensions. Since SFCL delivers services primarily targeting people to acquire economic strength. This could be stepping-stone to enter in empowering socio-economic perspectives. In addition of economic support, SFCL delivers services to women to uplift sociocultural standard. Service delivery system of SFCL does not directly support to encourage women in political activities, though it implies in political sense. It has emphasized women for microcredit programs in material resources and their control over it. In addition of economic aspects, role of SFCL is significantly higher in socio-cultural empowerment than the political empowerment. SFCL being an independent and non-political organization, people do not discuss in political issues, but indirectly women become aware on their political rights. The statistical analysis of ttest also shows the significant difference in socio-cultural and political empowerment of women after involvement in it. 


\section{REFERENCES}

"Women in National Parliaments. (2000, Dec 15). Retrieved Feb 29, 2017, from InterParliamentary Union, : <http://www.ipu.org/wmn-e/arc/world151200.htm>

Ahmed, M. (1999). Social Economic Baseline Survey: Pat Feeder Command Area Baluchistan. Government of Baluchistan.

Akram, D. S., Shaheen, I., \& Kiyyani, S. M. ( 2015). SOCIO-ECONOMIC EMPOWERMENT OF WOMEN THROUGH MICRO ENTERPRISES: A CASE STUDY OF AJK. European Scientific Journal edition, 11 (22).

De, S., \& Sarker, D. (2011). Women's Empowerment through Self-help Groups and its Impact on Health Issues: Empirical Evidence. Journal of Global Analysis, 2 (1), 51-82.

Esplen, E., \& Brody, A. (2007). Putting Gender Back into Picture: Rethinking Women 's Economic Empowerment. (BRIDGE-Gender) Institute of Development Studies.

Ibarraran, P., \& Shady, D. (2009). Evaluating the Impact of job-Training Programs in Latin America: Evidence from IDB Funded Operations InterAmerican Development Bank. The journal of Development Effectiveness, 1 (2), 195-216.

Khan, A., \& Bibi, Z. (2011). Women's Socio Economic Empowerment through Participatory Approach, a Critical Analysis. Pakistan Economic and Social Review, 49 (1), 133-148.

Kulkarni, V. S. (2011). Women's empowerment and microfinance An Asian perspective study. nternational Fund for Agricultural Development (IFAD).

Losindilo, E., AS Mussa, A., \& Akarro, R. (2010). Some Factors That Hinder Women Participation in Social, Political and Economic Activities in Tanzania. Arts and Social Sciences Journal, $4,1-10$.

Mariadoss, S. (2012). Women empowerment through micro enterprises. International journal of Physical and Social Sciences, 3, 42-48.

Microcredit Summit Campaign. (2007). Small change, Big changes:Women and Microfinance. Geneva: International Labor Office.

Mokate, K. (2004). Women's Participation in Social Development. Washington, D.C.: InterAmerican Institute for Social Development.

Paula, M. d. (2015, May 21). Feminism and Gender democracy. Retrieved Feb 29, 2017, from HEINRICH BOLL STIFTUNG: http://www.gwi-boell.de/en/2015/05/21/brazil-womensparticipation-elections

Rathiranee, Y. (2012). The Impact of Micro Credit on Women Empowerment. International Journal of Research in Commerce, Economics \& Management (IJRCM), 2.

Upadhyay, R. (2009). Women Empowerment in India. An Analytical Overview. Delhi: Asian Foundation.

Women in National Parliament. (2014, May 1). Retrieved Feb 29, 2017, from Inter-Parliamentary Union, : <http://www.ipu.org/wmn-e/classif.htm>. This Figure excludes the Holy See

Women in National Parliaments. (1997, Jan 1). Retrieved Feb 29, 2017, from Inter-Parliamentary Union: www.ipu.org/wmn-e/arc/world010197.htm> 